\title{
Model Pembelajaran Berbasis Komik Untuk Mencapai Ranah Afektif Pada Pendidikan Kewarganegaraan Bagi Anak Berkesulitan Belajar
}

\author{
Ari Wahyudi \\ FIP Unesa, e-mail:ari_plb65@yahoo.com
}

\begin{abstract}
Abstrak: Target peneliti ini adalah menciptakan terobosan belajar melalui paket komik berupa materi Pendidikan Kewarganegaraan yang dikemas dengan cerita sederhana dan gambar yang menarik dari kondisi kehidupan nyata sehari-hari anak. Dengan desain penelitian pengembangan dan teknik pengumpulan data observasi, wawancara, dan tes dihasilkan penelitian sebagai berikut: a) tahun pertama menghasilkan prototipe pembelajaran berbasis komik pada pendidikan kewarganegaraan, dan b) tahun kedua menghasilkan uji efektivitas pencapaian ranah afektif dalam pembelajaran pendidikan kewarganegaraan dengan penerapan model pembelajaran berbasis komik pada anak berkesulitan belajar yang sangat signifikan di kabupaten Sidoarjo, kabupaten Mojokerto dan kota Surabaya. Hasil akhir penelitian ini adalah buku komik belajar untuk kelas 3, kelas 4 dan kelas 5 yang telah mendapatkan pengesahan berupa ISBN.
\end{abstract}

Kata kunci: pembelajaran berbasis komik, ranah afektif, dan anak berkesulitan belajar

\begin{abstract}
The research target was to create a learning innovation through comic package in the form of civilization education which was packed by simply story and interesting picture from the daily life of children. By using developing research and collecting data technique such as observation, interview, and test it was resulted as the following: a) the first year resulted prototype learning base-comic to civilization education, and b) the second year resulted effectiveness test of attaining affective domain in learning civilization education by applying learning model base-comic for difficulty learning children who was very significant in Sidoarjo District, Mojokerto District and Surabaya city. The end of this result is comic book for third, the fourth, and fifth classes which had got ISBN.
\end{abstract}

Key words: learning base-comic, affective domain and difficulty learning children

\section{Pendahuluan}

Kedudukan guru sebagai orang tua kedua mengandung makna, bahwa masyarakat dan negara memberikan kepercayaan kepada guru untuk mendidik anak selama mereka berada di sekolah. Keberadaan anak di sekolah bukan hanya menuntut ilmu pengetahuan, melainkan belajar dan bergaul sesama siswa dengan semua guru. Semua anak menerima pengaruh pergaulan, bahkan dengan sadar menyerap contoh dan keteladanan yang dialami atau diamati mereka.

Anak usia sekolah dasar, sikap kritisnya mulai berkembang, karena itu apa yang mereka amati dan saksikan dari sesama teman maupun para guru, mereka serap atau tiru. Tingkah laku meniru itu, karena mereka mulai belajar bagaimana hidup, bersikap dan bertingkah laku. Sesungguhnyalah, mereka belum sadar benar antara yang benar dan baik, dengan suatu tindakan atau tutur kata yang salah dan kurang baik. Jadi, mereka perlu dibimbing di dalam sikap hidup, sopan santun dan tatakrama.

Untuk membina sikap hidup sopan dan bertatakrama, tidak cukup dengan uraian pelajaran (teori) panjang lebar, melainkan perlu dengan contoh dan tindakan nyata. Uraian katakata atau verbalisme akan kurang bermakna dibandingkan dengan sikap, contoh dan tindakan nyata. Untuk itu pribadi guru di dalam dan di luar kelas adalah pusat perhatian siswa, cita ideal, atau tokoh idola mereka. Karena itu pribadi sang guru hendaknya bersikap dan berlaku selalu memancarkan keteladanan.

Di samping itu kemampuan dan kemauan guru dengan seni (kiat) mendidik, dapat memikat anak didik dalam pembelajaran untuk bersama-sama 
mencapai tujuan. Guru sebagai pengelola kelas berarti pengendali arah proses belajar mengajar. Teori kependidikan mengajarkan bahwa anak didik bukanlah objek pendidikan atau objek pengajaran, melainkan sebagai subjek didik yang potensi pribadinya mengalami dengan sadar dan aktif dalam proses belajar mengajar. Proses belajar adalah auto aktivitas atau kegiatan mandiri menjalani kurikulum sebagai landasan pacu menuju tujuan.

Perlu disadari oleh guru bahwa di samping potensi subjek didik cukup baik, kondisi lingkungan belajar mengajar seyogyanya menunjang agar dapat menjamin keberhasilan proses belajar mengajar. Kondisi penunjang ini, adalah sikap guru yang mendorong dan menumbuhkan motivasi serta sarana media belajar mengajar yang memadai. Dengan kondisi yang memadai subjek didik akan aktif belajar, dengan berjalan di depan untuk menghadapi dan memecahkan masalah-masalah pengajaran, sementara guru berjalan di belakang tut wuri handayani.

Mengajarkan Pendidikan Pancasila dan Kewarganegaraan (PPKn) yang dalam kurikulum 2004 tergabung dalam Pendidikan Kewarganegaraan dan Pendidikan Sosial (PKPS) berpusat dan berinti pada nilai moral dan bela negara. Guru wajib mengidentifikasikan dirinya dengan nilai-nilai dan praktik asas-asas moral, artinya guru selalu dijiwai dan dilandasi nilai moral. Pendidikan Kewarganegaraan banyak menuntut pada perilaku moral atau ranah afektif dalam proses pembelajaran. Oleh karena itu guru harus kreatif mencari metode dan media yang sesuai dengan kondisi perkembangan belajar anak. Hal ini sesuai dengan penjelasan isi pasal 36 ayat 3 UndangUndang Nomor 20, Tahun 2003 (UU 20/2003), yang intinya bahwa kurikulum disusun sesuai dengan jenjang pendidikan dalam kerangka Negara Kesatuan Republik Indonesia dengan memperhatikan peningkatan iman dan takwa; peningkatan akhlak mulia; peningkatan potensi, kecerdasan, dan minat peserta didik; keragaman potensi daerah dan lingkungan; tuntutan pembangunan daerah dan nasional, tuntutan dunia kerja, perkembangan ilmu pengetahuan, teknologi dan seni, agama, dinamika perkembangan global dan persatuan nasional dan nilai-nilai kebangsaan (UU 20/ 2003).
Kurikulum yang diamanatkan dalam UU 20/ 2003 pasal 36 tersebut tidak akan dapat diwujudkan oleh anak didik dalam kehidupan sehariharinya apabila guru hanya menjelaskan atau memberikan ceramah secara panjang lebar materi itu, apalagi untuk anak berkesulitan belajar. Hal ini akan membuat anak lekas bosan dan akan antipati terhadap materi-materi yang ada. Ada dukungan data sebelumnya (mata pelajaran masih bernama PMP dan PSPB) bahwa hasil pooling dari 150 responden pelajar tentang segala sesuatu yang perlu dilakukan untuk meningkatkan rasa patriotisme di kalangan generasi muda dan pooling kembali 113 responden menunjukkan hasil $91,15 \%$ masih melihat perlunya peninjauan kembali materi PMP dan PSPB. Alasan yang dapat dihimpun adalah 23 responden $(20,35 \%)$ melihat apa yang diberikan dalam materi pelajaran PMP dan PSPB masih terlalu bersifat teoritis sehingga tidak jelas; 5 (4,42\%) responden melihat contohcontoh yang ada pada materi terlalu membingungkan, 75 responden $(66,37 \%)$ memberikan alasan perlu adanya tambahan contoh kongkrit untuk menunjang teori yang terdapat pada materi pelajaran itu, dan 10 responden $(8,84 \%)$ tidak memberikan komentar pada pernyataan itu (Surya; 1 Oktober 1990). Masalah demikian bila tidak diantisipasi secara dini dengan memberikan contoh kongkrit materi Pendidikan Kewarganegaraan yang muncul sejak diberlakukan kurikulum 1994 dalam bentuk perilaku nyata maka akan terjadi permasalahan yang sama (PMP dan PSPB pada kurikulum 1987).

Oleh karena itu, melalui penelitian ini, diasumsikan bahwa sikap yang dituntut dalam mata pelajaran Pendidikan Kewarganegaraan akan efektif dapat dijalankan oleh peserta didik terutama anak usia sekolah dasar, apabila ada media hiburan yang sangat disenangi anak melalui contoh-contoh perilaku lewat media komik belajar. Dari media permainan "komik" tersebut perlu diciptakan desain yang menarik antara gambar dengan isi materi sehingga komik belajar dapat menjadi hiburan anak sekaligus membelajarkan anak melalui pesan di dalamnya. Adapun rumusan masalah dalam penelitian ini adalah sebagai berikut: 1) Apakah ada efektivitas pencapaian ranah afektif dalam pembelajaran pendidikan kewarganegaraan dengan penerapan model 
pembelajaran berbasis komik pada anak berkesulitan belajar? 2) Bagaimana bentuk produk akhir model pembelajaran berbasis komik pada pendidikan kewarganegaraan?

Penelitian bertujuan untuk: 1) mengkaji ada tidaknya efektivitas pencapaian ranah afektif dalam pembelajaran pendidikan kewarganegaraan melalui penerapan model pembelajaran berbasis komik pada anak berkesulitan belajar, 2) mengembangkan model pembelajaran berbasis komik sebagai produk akhir untuk pendidikan kewarganegaraan bagi anak berkesulitan belajar.

\section{Kajian Literatur}

Persoalan besar yang dihadapi anak berkesulitan belajar adalah minat belajar yang rendah dan belajar yang cepat bosan, apalagi menghadapi materi Pendidikan Kewarganegaraan yang penuh dengan kebiasaan cerita. Data Pusbang Kurrandik Balitbang Diknas hasil penelitian dari 4994 siswa ditemukan sebanyak 696 siswa berkesulitan belajar atau 13,9 \% (Widyastono,1996). Jumlah tersebut cukup fantastik untuk ditangani secara intensif. Oleh karena itu, melalui penelitian ini telah ditemukan terobosan/solusi terhadap salah satu kesulitan anak pada materi Pendidikan Kewarganegaraan dengan memberikan paket belajar berbasis komik. Asumsi yang mendasari adalah belajar dengan kesenangan melihat gambar dan memahami isi cerita akan mendorong minat belajar dan mengurangi rasa bosan anak. Apabila dua persoalan itu dapat diatasi harapannya adalah prestasi anak akan meningkat. Asumsi ini diperkuat temuan bahwa anak tunagrahita di Sidoarjo dapat mencapai ranah afektif dalam pembelajaran PPkn melalui bentuk permainan seperti panggung boneka (Wahyudi, 1999; Sujarwanto, 1999), ular tangga (Wahyudi, 2003) dan cerita bergambar (Wahyudi, 2004).

Anak berkesulitan belajar merupakan bidang garapan yang masih relatif muda dalam dunia pendidikan luar biasa (Soemantri,1996). Bahkan anak ini termasuk ke dalam kelompok tersendiri yang disebut learning disabilities. Prevalensi anak berkesulitan belajar di sekolah menurut beberapa literatur rentangnya berkisar antara 1-30\% (Learner, 1981), 2-30 \% (Lovitt,1989), dan diperkirakan mencapai $15 \%$ dari populasi anakanak SD (Geddes,1985). Hasil survey terhadap 25
SDN di DKI tahun 1994 ditemukan 16,52 \% anak yang dinyatakan oleh guru sebagai berkesulitan belajar (Mulyono \& Ibrahim,1994).

Data tersebut menunjukkan bahwa kesulitan belajar perlu ada terobosan penanganan yang intensif. Murtadlo (2005) telah melakukan upaya untuk meningkatkan prestasi belajar anak berkesulitan belajar di SDN Waru I dan Waru IV melalui pendekatan kooperatif tipe TAI hasilnya cukup signifikan. Lain halnya dengan Hidayah (2003) dengan mencoba meningkatkan kemampuan guru untuk menangani anak berkesulitan belajar, hasilnya bahwa ada perbedaan prestasi belajar anak berkesulitan belajar sebelum dan sesudah pelaksanaan intervensi guru kelas yang memiliki kemampuan menangani anak berkesulitan belajar.

Sebagai rujukan teori bagi peneliti dalam upaya menangani anak berkesulitan belajar adalah upaya mengidentifikasi kesulitan belajar anak. Jika yakin bahwa karakteristik utama kesulitan belajar itu adalah hiperaktif dan masalah perseptual motorik maka prosedur identifikasi akan diarahkan ke sana; jika masalah bahasa maka identifikasi akan difokuskan pada pengukuran keterampilan berbahasa. Dengan demikian identifikasi anak berkesulitan belajar akan bergantung pada definisi, orientasi dan prosedur evaluasi yang digunakan (Somantri, 2006).

Kendatipun demikian prinsip-prinsip dasar evaluasi bagi anak berkesulitan belajar perlu diketahui dan difahami, yaitu: 1) tes atau teknik evaluasi lain harus diberikan dalam bahasa anak/ dapat difahami oleh anak, 2) tidak ada prosedur tunggal yang bisa digunakan untuk menentukan program pendidikan yang layak bagi anak berkesulitan belajar, 3) evaluasi harus dilakukan oleh tim dari berbagai disiplin, setidak-tidaknya terdiri atas seorang guru atau ahli lain yang mengetahui masalah kesulitan belajar. Dan secara umum, perilaku bermasalah yang muncul dari kesulitan belajar terutama akan terkait dengan masalah penyesuaian diri maupun akademik anak, hubungan sosial, stabilitas emosi. Bagi anak sendiri kondisi seperti ini dapat menimbulkan frustasi atau cemas yang berlebihan karena dia selalu mengalami kegagalan dalam memenuhi tuntutan dan tugas belajar atau dengan kata lain 
dalam banyak hal anak tidak mampu menguasai tugas-tugas perkembangan yang harus dicapainya.

Terobosan yang harus diberikan adalah bagaimana membuat belajar anak yang berkesulitan belajar tidak lekas bosan. Dalam kajian ini ditelaah penerapan model pembelajaran permainan yang berbasis menyenangkan berupa komik belajar. Dari penelitian-penelitian yang telah dilakukan oleh para ilmuwan, diperoleh temuan bahwa bermain mempunyai manfaat yang besar bagi perkembangan anak. Bermain merupakan pengalaman belajar yang sangat berguna bagi anak, misalnya saja memperoleh pengalaman dalam membina hubungan dengan sesama teman, menambah perbendaharaan kata, menyalurkan perasaan-perasaan yang tertekan (Hurlock, 1993).

Salah satu mainan yang sangat disukai masa anak-anak adalah permainan ular tangga, panggung boneka, monopoli dan termasuk cerita bergaambar. Usia TK sampai SD kelas 3, kegiatan bermain pura-pura sangat banyak dilakukan. Dalam bermain pura-pura anak menirukan kegiatan orang yang pernah dijumpainya dalam kehidupan sehari-hari. Dapat juga anak melakukan peran imajinaatif, memainkan peran tokoh yang dikenalnya melalui film kartun atau dongeng. Misalnya mainan rumah-rumahan, polisi dan penjahat, jadi batman atau ksatria baja hitam, berperan sebagai ibu dan sebagainya. Sarana imajinatif yang sangat baik untuk usia anak TKSD kelas rendah atau SLB adalah figur permainan yang dapat dikomunikatifkan dengan dirinya. Pada umumnya setiap anak menyukai permainan yang sesuai dengan tingkat usia dan tingkat kepandaiannya.

Sejalan dengan pendapat Sudjana (1991), bahwa manfaat media pengajaran adalah yang menarik perhatian siswa dan menimbulkan motivasi belajar. Lebih lanjut ditandaskan Sudjana bahwa dengan alat peraga siswa lebih banyak melakukan kegiatan belajar, sebab tidak hanya mendengarkan guru tetapi juga aktivitas lainnya.

Drijarkara (1969) mengatakan bahwa penanaman sikap terhadap siswa tentang Tuhan adalah manusia belumlah mengerti akan Tuhan betul-betul selama dia belum berdoa, tetapi disamping dan bersama doa yang dipanjatkan
Tuhan akan bersamanya. Perbuatan praktis manusia dikatakan lebih lanjut bahwa jika manusia melaksanakan wajibnya sehari-hari dengan sebaik-baiknya, terutama wajib-wajib yang langsung pengabdian kepada sesama manusia maka Tuhan akan bersamanya. Dari pernyataan tersebut di hadapan Tuhan, manusia yang normal dan tidak normal, yang cacat dan yang tidak cacat, laki-laki, perempuan, tua muda mempunyai hak dan kedudukan yang sama dihadapan Tuhan. Demikian pula halnya bagi anak tunagrahita, walaupun kemampuan mereka lebih rendah daripada manusia lainnya yang normal, mereka ini seakan-akan telah disediakan pertanggungjawaban yang sesuai dengan kemampuannya. Mereka perlu dididik untuk menghormati dan mencintai Tuhan penciptanya melalui cara-cara diperkenalkan dengan segala keagungan-Nya, kesabaran-Nya dan kemurahanNya. Proses penanaman nilai ini merupakan peranan guru dalam proses belajar yang dituntut kreatif mencari jalan keluar untuk mengatasi kebosanan siswa pada pelajaran, terutama siswa berkesulitan belajar.

Dikatakan Wahyudi (1997) dalam penelitian tentang menggugah kepedulian masyarakat untuk mengembangkan potensi penyandang cacat melalui wayang kulit di Jawa Timur, bahwa media-media komunikatif yang dapat digunakan untuk proses interaksi perlu diupayakan untuk mengertikan sesuatu pada orang lain. Proses interaksi tersebut membawa dampak yang cukup baik terhadap pembentukan sikap masyarakat. Atas dasar ini jelas bahwa media-media komunikatif seperti panggung boneka, ular tangga, media cerita bergambar, permainan monopoli dan komik belajar seperti ini dapat mengatasi kebosanan siswa di dalam kelas apalagi untuk anak berkesulitan belajar.

Dikatakan Ghazah dalam Ahmadi dan Rohani (1991) salah satu prinsip pengajaran yang penting adalah prinsip peragaan yang menekankan pada penggunaan alat peraga agar siswa mudah mengingat dan memahami bahan pelajaran yang disampaikan guru. Agar peserta didik mudah mengingat, menceritakan dan melaksanakan sesuatu pelajaran yang pernah diamati di dalam kelas perlu didukung media pengajaran yang kongkrit. Apalagi bagi individu- 
individu yang masih sangat butuh perangsang sesuatu yang serba kongkrit dan jelas.

Setyowati (1996) menandaskan bahwa alat peraga telah difungsikan secara optimal dalam proses belajar mengajar yang meliputi kegiatan penyajian materi, pengerjaan LKS dan pemberian umpan balik, maka proses belajar mengajar dapat berjalan lancar dan efisien. Bahkan lebih menarik dan bersemangat untuk belajar. Di sini jelas bahwa unsur bermain dalam belajar memiliki peranan yang cukup besar untuk menggairahkan semangat anak.

Hasil kajian Wahyudi (2003) tentang penerapan permainan ular tangga untuk kegiatan pembelajaran anak tunagrahita dijelaskan bahwa permainan ular tangga dengan kartu kendali yang jelas sesuai dengan pokok bahasan akan menjadi media yang komunikatif dan cukup menggembirakan anak dalam proses pembelajaran terutama bagi anak tunagrahita. Sebagai catatan dalam kajian ini adalah apabila guru tidak kreatif membuat kartu kendali dengan bahasa yang komunikatif siswa juga akan menjadi bosan.

Lebih lanjut, dikatakan Ulfah (2004:11-22) bahwa media komik transparansi disukai anak SD karena melalui identifikasi dan karakter di dalam komik, siswa memperoleh kesempatan yang baik untuk mendapatkan wawasan mengenai masalah pribadi dan sosialnya; komik menarik imajinasi siswa; komik mudah dibaca, bahkan anak yang kurang mampu membaca sekalipun dapat memahami arti dari gambar itu.

Dari penelitian-penelitian yang telah dilakukan oleh para ilmuwan, diperoleh temuan bahwa bermain mempunyai manfaat yang besar bagi perkembangan anak. Bermain merupakan pengalaman belajar yang sangat berguna bagi anak, misalnya saja memperoleh pengalaman dalam membina hubungan dengan sesama teman, menambah perbendaharaan kata, menyalurkan perasaan-perasaan yang tertekan (Hurlock, 1993).

Salah satu mainan yang sangat disukai masa anak-anak adalah permainan ular tangga, panggung boneka, monopoli dan termasuk cerita bergaambar. Usia TK sampai SD kelas 3, kegiatan bermain pura-pura sangat banyak dilakukan. Dalam bermain pura-pura anak menirukan kegiatan orang yang pernah dijumpainya dalam kehidupan sehari-hari. Dapat juga anak melakukan peran imajinatif, memainkan peran tokoh yang dikenalnya melalui film kartun atau dongeng. Misalnya mainan rumah-rumahan, polisi dan penjahat, jadi batman atau ksatria baja hitam, berperan sebagai ibu dan sebagainya. Sarana imajinatif yang sangat baik untuk usia anak TKSD kelas rendah atau SLB adalah figur permainan yang dapat dikomunikatifkan dengan dirinya. Pada umumnya setiap anak menyukai permainan yang sesuai dengan tingkat usia dan tingkat kepandaiannya.

Permainan cerita bergambar bila dikelompokkan pada perkembangan bermain termasuk mengembangkan social play. Permainan sosial ini merupakan tonggak penting dalam tahapan perkembangan sosial anak. Melalui kegiatan bermain sosial tampak bahwa egosentrisme anak semakin berkurang, dan anak secara bertahap berkembang menjadi makhluk sosial yang bergaul dan menyesuaikan diri dengan lingkungan sosialnya. Kegiatan bermain sosial ditandai dengan adanya interaksi dengan orang lain disekeliling anak, sehingga akhirnya anak mampu terlibat dalam kerjasama dalam bermain. Lawrence Sherman (1975) dalam Stassen Berger (1983) menemukan suatu bentuk unik bermain sosial pada anak prasekolah, yang disebutnya group glee atau kegembiraan bersama. Sekelompok anak secara bersama-sama akan tertawa, meloncat-loncat, bertepuk tangan riang tanpa adanya kejadian yang benar-benar lucu. Misalnya, anak-anak bersorak riuh rendah hanya karena ada anak lain yang menumpahkan minumannya, atau tertawa-tawa hanya karena saling menghindari sentuhan masing-masing dan semacamnya.

Permainan yang dikembangkan Lawrence Sherman ini dapat diadopsikan pada permainan cerita bergambar yang diarahkan pada pembentukan nilai sosial di dalamnya penanaman perilaku hidup sehari-hari peserta didik. Sehingga bermain dan berteman dengan bersukaria apabila cerita bergambar itu tidak dimengerti oleh anak dan merasa senang. Permainan ini akan membikin ketawa peserta sekaligus siswa dapat menyeleksi perilaku yang baik dalam kehidupannya. 
Dengan meningkatnya usia, anak perlu belajar berpisah dengan pengasuhnya atau ibunya, ia butuh diyakinkan bahwa perpisahan itu hanya berlangsung sesaat saja. Misalnya saja melalui permainan 'ciluk-ba dan petak umpet' ia akan memperoleh pengalaman tersebut. Dengan teman sepermainan yang sebaya usianya, anak akan belajar berbagai hak milik, menggunakan mainan secara bergilir, melakukan kegiatan bersama, mempertahankan hubungan yang sudah terbina, mencari cara pemecahan masaalah yang dihadapi dengan teman mainnya. Misalnya saja bagaimana membuat aturan permainan sehingga pertengkaran dapat dihindari.

Permainan cerita bergambar yang dapat dimanfaatkan sebagai media pembelajaran, akan juga dapat digunakan sebagai belajar berkomunikasi dengan sesama teman baik dalam hal mengemukakan isi pikiran dan perasaannya maupun memahami apa yang diucapkan oleh teman tersebut, sehingga hubungan dapat terbina dan dapat saling bertukar informasi/ pengetahuan. Perlu juga diingat peran bermain sebagai media bagi anak untuk mempelajari budaya setempat, peran-peran sosial dan peran jenis kelamin yang berlangsung di dalam masyarakat. Anak akan mewarisi permainan yang khas sesuai dengan budaya masyarakat tempat ia hidup. Dari sini ia akan belajar tentang sistem nilai, kebiasaan-kebiasaan dan standar moral yang dianut oleh masyarakatnya.

Ranah affektif dalam proses pembelajaran pada umumnya dan khususnya Pendidikan Kewarganegaraan, telah diberikan petunjuk oleh Binyamin S. Bloom dalam kreteria yang dikenal dengan taxonomi tujuan pengajaran (Taxonomi Bloom) aspeknya meliputi: 1) Kemampuan menerima (Receiving) yang meliputi aktivitas diantaranya; mendengarkan dengan perhatian, menunjukkan kesadaran akan pentingnya belajar, menunjukkan sensitifitas akan keperluan manusia dan persoalan-persoalan masyarakat, menerima berbagai kebiasaan, menerima dengan baik segala aktivitas kelas, 2) Kemampuan partisipasi (Responding), meliputi aktivitas diantaranya; melengkapi pekerjaan rumah yang ditentukan, mentaati peraturan sekolah, ikut serta dalam diskusi-diskusi sekolah, melengkapi karya laboratorik, sukarela melaksanakan tugas-tugas khusus, menyukai dalam menolong orang lain, 3) Penilaian/Penentuan Sikap (Valuing), meliputi aktivitas, menunjukkan kepercayaan akan proses demokrasi, menghargai kepercayaan yang baik, menghargai peranan pengetahuan dalam kehidupan sehari-hari, menunjukkan perhatian dan kesejahteraan orang lain, menunjukkan sikap pemecahan masalah, menunjukkan rasa waajib terhadap perbaikan masyarakat, 4) Organisasi (Organization), meliputi aktivitas, mengenal perlunya keseimbangan antara kebebasan dan tanggung jawab dalam demokrasi, mengenal peranan perencanaan yang sistematik, menerima tanggung jawab bagi perilakunya sendiri, memahami dan menerima kekuatannya dan keterbatasannya, merumuskan rencana kehidupan yang selaras dengan kemampuannya, perhatiannya dan keyakinannya, 5) Pembentukan Pola Hidup (Characterization by a value complex), meliputi aktivitas, menunjukkan keinsyafan yang benar, menunjukkan kepercayaan diri untuk bekerja sendirian, mempraktekkan kerja sama dalam aktivitas kelompok, menggunakan langkahlangkah obyektif dalam pemecahan masalah, menunjukkan ketentuan, ketelitian dan disiplin pribadi, mempertahankan kebiasaan yang sehat (Rohani \& Ahmadi, 1991).

Mengingat penilaian mata pelajaran PKn bukan aspek penalaran semata-mata, maka keputusan guru dalam menetapkan nilai jangan sampai mengorbankan harga diri dan kepribadian anak. Bahkan guru berkewajiban mendorong anak untuk tetap dan selalu setia dan mencintai Pancasila dasar negara kita.

Apabila akibat nilai Pancasila siswa menderita (tidak naik kelas atau tidak lulus), siswa akan membenci dan dendam kepada guru. Mungkin juga benci kepada nilai Pancasila. Bila hal demikian terjadi, guru gagal membina nilai dan moral Pancasila. Oleh karena itu pencapaian ranah afektif dalam mata pelajaran PPKn tidak dapat dilakukan guru hanya sekedar teori panjang lebar, tetapi membutuhkan kiat untuk mencari media dan metode yang mudah dipahami dan mudah diidentifikasi oleh peserta didik, apalagi untuk anak usia sekolah dasar. 


\section{Metodologi}

Penelitian ini merupakan penelitian pengembangan dan penelitian eksperimen dengan desain praeksperimen. Penelitian pengembang an (Development research) menurut model Borg and Gall (2003) dengan menggunakan 5 langkah utama yaitu:1) melakukan analisis produk yang akan dikembangkan, 2) mengembangkan produk awal, 3) validasi ahli dan revisi, 4) ujicoba lapangan skala kecil dan revisi produk dan 5) ujicoba lapangan skala besar dan produk akhir. Model Borg and Gall ini digunakan untuk uji kelayakan produk melalui model pembelajaran berbasis komik yang dikembangkan. Rancangan pra eksperimen digunakan untuk uji kehandalan produk dan melihat pencapaian ranah afektif dalam pembelajaran Pendidikan Kewarganegaraan di SD dan model yang diterapkan adalah one group pre-test post test design serta dianalisis dengan rumus statistik sign test .karena sampel kecil.

Penelitian tahun pertama dengan mengacu tahapan Borg and Gall telah dicapai tahap ke-4 yaitu menghasilkan komik mata pelajaran Pendidikan Kewarganegaraan untuk SD kelas 4,5. Untuk kelas 3 dikembangkan pada tahun kedua karena terkendala pada perubahan kurikulum. Adapun tahapan yang telah dicapai: 1) tahap menganalisis produk yang akan dikembangkan (tahap persiapan), yaitu menyiapkan penyusunan komik meliputi klarifikasi materi Pendidikan Kewarganegaraan yang bersumber dari GBPP, mendesain isi cerita berdasarkan pokok bahasan tiap kelas, mendesain gambar-gambar yang relevan dengan cerita, 2) tahap mengembangkan produk awal (tahap pelaksanaan), yaitu menggambar cerita sesuai desain yang dibuat sampai selesai, setting menuju percetakan dan penjilidan hasil, 3) tahap validasi ahli dan revisi, yaitu secara terbatas hasilnya dievaluasi oleh ahli komik, akademisi dan guru SD, 4) tahap ujicoba lapangan skala kecil dan revisi produk, uji terbatas skala kecil pada 4 SDN yang siswanya mengalami kesulitan belajar di kabupaten Mojokerto (SDN Kauman kecamatan Mojosari, SDN Sawahan Kecamatan Bangsal, SDN Randubangu Kecamatan Pungging dan SDN Modopuro kecamatan Trawas) dan hasil ujicoba dilakukan revisi komik dari sisi ahli komik (kaidah komik, ekspresi gambar dan pesan, konsistensi gambar dalam cerita) dan dari sisi praktisi (isi materi, dan bobot materi).

Penelitian tahun kedua, ada dua tahap yang dilakukan, yaitu: 1) langkah awal menganalisis hasil revisi oleh guru kelas dan tim peneliti, menyusun komik belajar untuk kelas 3 dengan kurikulum yang baru, langkah berikutnya mencetak menjadi buku komik dengan kapasitas buku belajar, 2) melakukan uji coba luas di tiga kabupaten (Mojokerto, Sidoarjo dan Surabaya) dan sekaligus melakukan eksperimen tentang pencapaian ranah afektif dalam pembelajaran Pendidikan Kewarganegaraan di SDN tersebut. Langkah akhir penelitian ini adalah penyempurnaan model pembelajaran berbasis komik sampai pada tingkat standar.

Subjek penelitian ini adalah anak berkesulitan belajar di SDN yang prevalensi kesulitan belajarnya tinggi (15-20\%) dari jumlah siswa yang ada, dari seluruh SDN sejumlah 15 SDN yang ada di tiga daerah penelitian, yaitu kabupaten Mojokerto, Sidoarjo dan kota Surabaya. Pelaksanaan penelitian di awali bulan Juni sampai dengan bulan Oktober 2008. Teknik pengambilan subjek penelitian dengan purposive sampling yang memperhatikan karakteristik: 1) siswa SDN yang benar-benar mengalami kesulitan belajar, 2) SDN yang ditetapkan adalah sekolah yang memiliki prevalensi kesulitan belajarnya mencapai $15-20 \%$, 3) siswa yang ditangani adalah siswa yang mampu membaca yaitu kelas 3,4,5.

Teknik pengumpulan data dalam penelitian ini adalah teknik observasi, wawancara dan tes. Teknik observasi dan wawancara digunakan untuk menghimpun data tentang kelayakan model pembelajaran berbasis komik, yaitu untuk menghimpun kendala-kendala operasional dan menghimpun data pendapat tim observer (ahli komik, akademisi dan guru kelas) terhadap kelayakan komik menjadi model pembelajaran pendidikan Kewarga-negaraan. Tes untuk mengukur pencapaian ranah afektif dalam pembelajaran siswa pada mata pelajaran Pendidikan Kewarganegaraan (tahun kedua).

Analisis data dilakukan dengan statistik deskriptif menggunakan rumus persentase tentang kelayakan model pembelajaran berbasis komik oleh pakar komik, akademisi dan guru kelas. Hasil analisis tersebut digunakan sebagai bahan 
penyempurnaan model pembelajaran. Untuk menganalisis tingkat pencapaian ranah afektif digunakan rumus statistik uji Sign Test untuk sampel kecil dari data hasil tes sebelum dan sesudah belajar komik di masing-masing sekolah.

\section{Hasil dan Bahasan}

Penelitian yang dihasilkan di tahun pertama adalah prototype tentang komik belajar untuk mata pelajaran pendidikan kewarganegaraan yang siap untuk diujicobakan secara luas di tiga kabupaten/kota yaitu Mojokerto, Sidoarjo dan Surabaya. Secara kronologis hasil penelitian di tahun pertama ini disajikan berikut ini. Pertama,karakteristik anak berkesulitan Belajar di SDN. Seorang anak dikatakan mengalami kesulitan belajar jika tidak mampu mencapai prestasi sesuai dengan usia dan tingkat kecakapan dalam bidang:a) ekspresi lisan, b) mendengarkan pemahaman, c) ekspresi tulisan, d) keterampilan membaca dasar, e) membaca pemahaman, f) perhitungan matematis, atau g) berpikir matematis. Untuk kepentingan penelitian ini yang termasuk anak berkesulitan belajar adalah anak yang tidak mampu mencapai prestasi sesuai dengan usia dan tingkat kecakapan dalam bidang mendengarkan dan membaca pemahaman. Kedua, pengembangan model pembelajaran berbasis komik untuk mata pelajaran pendidikan kewarganegaraan bagi anak berkesulitan belajar berupa prototipe yang telah mendapat masukan dari tim ahli, praktisi dan anak berkesulitan belajar melalui uji terbatas.

Hasil penelitian di tahun kedua merupakan hasil eksperimen pada 5 SDN yang ada di kota Surabaya, 5 SDN di kabupaten Mojokerto dan 5 SDN di kabupaten Sidoarjo. Jadi keseluruhan ada 15 SDN dengan analisis statistik rumus sign test. Hasil pengkajian dapat diuraikan sesuai dengan rumusan masalah. 1) Efektivitas Pencapaian Ranah Afektif Pembelajaran Pendidikan Kewarganegaraan melalui Model Pembelajaran berbasis komik; (a) Wilayah kota Surabaya 4 SDN (SDN Alon-alon Contong, dengan nilai z hitung 3,83 $>$ dari nilai kritis 1,96, SDN Warugunung I dengan z hitung 2,40 > dari nilai kritis 1,96, SDN Bangkingan II dengan $z$ hitung 2,52 > dari nilai kritis 1,96, SDN Balasklumprik dengan z hitung $2,18>$ dari nilai kritis 1,96 ) hasilnya ada efektivitas yang cukup signifikan pencapaian ranah afektif pembelajaran Pendidikan Kewarganegaraan melalui pembelajaran berbasis komik, hal ini terbukti dengan hasil hitung nilai zh di atas nilai kritis 1,96 dan 1 SDN yang tidak menunjukkan efektivitas (SDN Gayungan II dengan z hitung 1,69 $<$ dari nilai kritis 1,96). Namun secara keseluruhan SDN di kota Surabaya efektivitas pencapaian ranah afektif pembelajaran Pendidikan Kewarganegaraan cukup signifikan dengan hitung 5,72 > dari nilai kritis 1,96.; (b) wilayah kabupaten Sidoarjo di 5 SDN (SDN Ketajen II dengan z hitung $3,89>$ dari nilai kritis 1,96 , SDN Wedi dengan $z$ hitung 2,27>dari nilai kritis 1,96, SDN Gedangrowo dengan $z$ hitung 2,53 > dari nilai kritis 1,96, SDN Krembung I dengan $z$ hitung $2,40>$ dari nilai kritis 1,96, dan SDN Tarik I dengan z hitung 2,27> dari nilai kritis 1,96$)$ menunjukkan efektivitas yang cukup tinggi pencapaian ranah afektif pembelajaran Pendidikan Kewarganegaraan melalui pembelajaran berbasis komik, (c) wilayah kabupaten Mojokerto (SDN Sawahan dengan z hitung 2,83 > dari nilai kritis 1,96 , SDN Sukosari dengan z hitung 3,36 > dari nilai kritis 1,96, SDN Wonosari I dengan $z$ hitung 2,68 > dari nilai kritis 1,96 , SDN Bangsal dengan $z$ hitung 2,71 > dari nilai kritis 1,96 , SDN Trowulan I dengan $z$ hitung 2,5 > dari nilai kritis 1,96 ) juga sama yaitu efektivitas yang cukup tinggi pencapaian ranah afektif pembelajaran Pendidikan Kewarganegaraan melalui pembelajaran berbasis komik. (2) Bentuk produk akhir model pembelajaran berbasis komik pada pendidikan kewarganegaraan adalah berupa komik belajar pendidikan kewarganegaraan setelah melalui perbaikan. Wujud akhirnya adalah buku komik yang telah mendapatkan pengesahan lewat ISBN dari buku kelas 3, kelas 4 dan kelas 5 .

Dengan demikian hasil penelitian ini menunjukkan bahwa: 1) ada efektivitas pencapaian ranah afektif dalam pembelajaran pendidikan kewarganegaraan dengan penerapan model pembelajaran berbasis komik pada anak berkesulitan belajar yang sangat signifikan di kabupaten Mojokerto, kabupaten Sidoarjo dan kota Surabaya; 2) Wujud akhir buku komik belajar yang telah mendapatkan pengesahan berupa ISBN. 


\section{Simpulan dan Saran}

\section{Simpulan}

Hasil penelitian ini dapat disimpulkan hal-hal sebagai berikut. Ada efektivitas pencapaian ranah afektif dalam pembelajaran pendidikan kewarganegaraan dengan penerapan model pembelajaran berbasis komik pada anak berkesulitan belajar di kabupaten Mojokerto, kabupaten Sidoarjo dan kota Surabaya. Bentuk produk akhir penelitian ini adalah buku komik belajar untuk kelas 3, kelas 4 dan kelas 5 yang telah dilengkapi dengan latihan soal dan buku ini telah mendapatkan pengesahan berupa ISBN.

\section{Saran}

Terkait dengan simpulan penelitian dapat disarankan agar guru kelas anak berkesulitan belajar selalu mengembangkan kreativitas mengajar dengan menggunakan media termasuk media komik. Bagi Dinas Pendidikan setempat agar memberikan pembinaan terhadap guru-guru SD melalui kegiatan KKG (Kelompok Kerja Guru) dalam hal pembuatan media pembelajaran yang inovatif.

\section{Pustaka Acuan}

Ahmadi, Abu \& Ahmad Rohani. 1991. Pengelolaan Pengajaran. Jakarta: Rineka Cipta.

Borg, W.R. and GII, M. D. 2003. Educational Research: An Introduction. London: Longman,Inc.

Drijarkara, N. 1969. Gambaran Manusia Pancasila. Yogyakarta: Paramita.

Geddes, 1985. Learning Disabilities and Brain Fuction. New York: Springer Verlag.

Hidayah, Noer. 2003. "Peningkatan Kemampuan Guru dalam Pembelajaran Anak Gangguan Gizi yang Mengalami Kesulitan Belajar di Sekolah Dasar", Jurnal Rehabilitasi \& Remediasi, No. 1 Tahun 13 Juni 2003 ISSN 0854-0020.

Hurlock, EB. 1993. Perkembangan Anak. (Alih Bahasa Meitasari Tjandrasa dan Muslichah Zarkasih). Jakarta: Erlangga.

Learner. 1981. Learning Disabilities. Boston: Houghton Miflin Company.

Lovitt. 1989. Instruction to Learning Disabilities. Boston: Allyn anda Bacon.

Mulyono \& Nafsiah Ibrahim. 1994. Survey tentang Jumlah Siswa SD di DKI Jakarta yang Membutuhkan layanan PLB. Jakarta: LP-IKIP.

Murtadlo.2005. "Peningkatan Prestasi Belajar Siswa Berkesulitan Belajar Membaca Menulis melalui Pendekatan Kooperatif Tipe TAI di SD". Jurnal Pendidikan Dasar No.1 Volume 5 Tahun 2005.

Setyowati, Nanik. 1996. Optimalisasi Penggunaan alat Peraga IPA dan IPS di Sekolah Dasar. Surabaya: Jurnal Riset No. 05/Th.III.

Somantri, Sutjihati. 2006. Psikologi Anak Luar Biasa. Jakarta: Depdikbud

Sujarwanto. 1999. Pencapaian Ranah Afektif dalam Pembelajaran PPKn di SLB Tunagrahita melalui Fragmen Panggung Boneka. Laporan Penelitian Tidak diterbitkan. Jurnal Pendidikan Dasar No.1 Vol 1 Tahun 2000 ISSN: 1411-285X. Surabaya : Unipress.

Sudjana, Nana. 1991. Media Pengajaran. Jakarta : Rajawali.

Surya Post 1 Oktober 1990. Pooling Memperingati Hari Kesaktian Pancasila tentang Materi PMP dan PSPB perlu Ditinjau Lagi. Surabaya: Media Surya Post.

Ulfah, Meuthia. 2004. Effektivitas pembelajaran dengan media panggung boneka dan komik transparansi dalam membentuk sikap moral siswa sekolah dasar. Jurnal Pendidikan Dasar. Volume 4 Nomor 2 September.

Undang-Undang Nomor 20 Tahun 2003. Sistem Pendidikan Nasional. Bandung: Citra Umbara.

Wahyudi, Ari. 1997. Menggugah Kepedulian Masyarakat untuk Mengembangkan Potensi Penyandang Cacat Melalui seni Wayang Kulit. Surabaya: Lembaga Penelitian IKIP Surabaya. 
Wahyudi, Ari. 1999. "Urgensi Panggung Boneka dalam Pembelajaran PPKn di SLB Tunagrahita Dharma Wanita Sidoarjo". Jurnal Media Pendidikan dan Ilmu Pengetahuan No. 4 Th. XXII tahun 1999,ISSN 0216-9975.

Wahyudi, Ari. 2003. Penerapan Permainan Ular Tangga sebagai Media Simulasi untuk Mencapai Ranah Afektif dalam Pembelajaran PPKn di SLB Tunagrahita. Surabaya: Lembaga Pengabdian Kepada Masyarakat (Laporan tidak diterbitkan).

Wahyudi, Ari. 2004. Penerapan Teknologi Media Cerita Bergambar untuk Mencapai Ranah Afektif dalam Pembelajaran PPKn di SLB Tunagrahita. Surabaya: Lembaga Pengabdian Kepada Masyarakat (Laporan tidak diterbitkan)

Widyastono, H. 1996. Profil Siswa SD yang Memerlukan Perhatian/Layanan Khusus dan Berkesulitan Belajar. Jakarta: Balitbang Dikbud. 